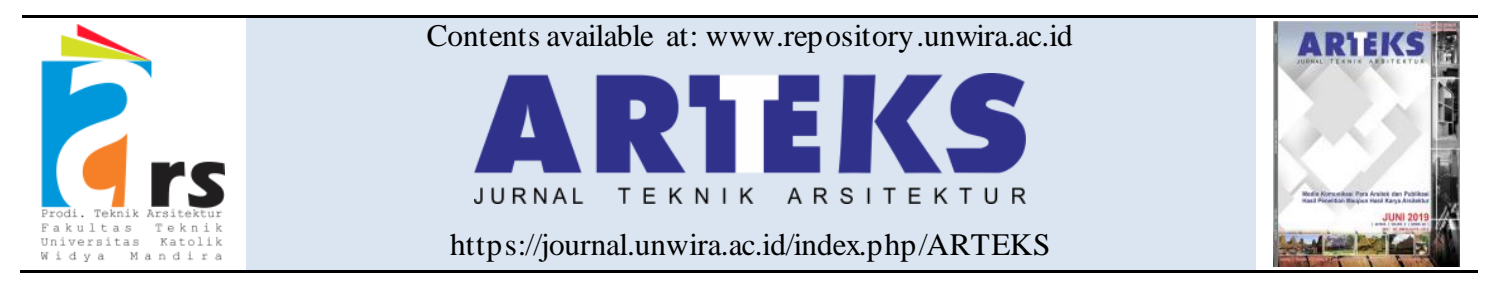

Research paper

doi: 10.30822/arteks.v6i1.662

\title{
Visual evaluation of the coastal area on Ayung river estuary in Denpasar City
}

\author{
I Made Agus Dharmadiatmika*, Anak Agung Keswari Krisnandika \\ Landscape Architecture Study Program, Faculty of Agriculture, Universitas Udayana \\ Jl. PB. Sudirman, Denpasar, Bali, Indonesia
}

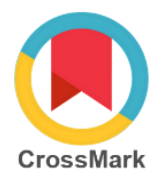

\begin{tabular}{|c|c|}
\hline ARTICLE INFO & ABSTRACT \\
\hline $\begin{array}{l}\text { Article history: } \\
\text { Received August } 26,2020 \\
\text { Received in revised form September } 17, \\
2020 \\
\text { Accepted November } 19,2020 \\
\text { Available online April } 01,2021 \\
\end{array}$ & $\begin{array}{l}\text { The development of coastal areas in Denpasar City is no longer } \\
\text { focused on one location in Sanur but rather prioritizes potential } \\
\text { tourism areas such as the Ayung river estuary in Kesiman } \\
\text { Kertalangu Village. This area has a beautiful natural landscape } \\
\text { which makes it a recreational destination for the surrounding } \\
\text { community and several efforts have been made by the village }\end{array}$ \\
\hline $\begin{array}{l}\text { *Corresponding author: I Made Agus } \\
\text { Dharmadiatmika } \\
\text { Landscape Architecture Study Program, } \\
\text { Faculty of Agriculture, Universitas Udayana, } \\
\text { Indonesia } \\
\text { Email: dharmadiatmika@unud.ac.id }\end{array}$ & $\begin{array}{l}\text { government to make it desirable for tourists as observed in the } \\
\text { evaluation of the beautiful landscape in Ayung river estuary to serve } \\
\text { as an input for further planning of the area. This research was, } \\
\text { therefore, conducted using a descriptive quantitative method and } \\
\text { scenic beauty estimation for analysis. The results showed the high } \\
\text { scenic beauty estimation (SBE) category was on the west side of the } \\
\text { Ayung River while the low category was in the coastal area to the } \\
\text { north of the area. Moreover, the factors influencing the scenic } \\
\text { beauty estimation (SBE) value include vegetation, water elements, } \\
\text { cleanliness, and the aesthetic form of hardscapellandscape } \\
\text { elements. }\end{array}$ \\
\hline
\end{tabular}

\section{Introduction}

Several efforts have been implemented in Bali through the management of natural resources to provide support for regional development. The focus is mostly on tourism potentials based on the natural beauty from mountains to coastal areas in almost all districts and cities in Bali Province (Budihardjo 2019). Moreover, statistical data showed the foreign tourist visits to Bali reached 517,889 which is an 11.35 percent increase from 2017 (Badan Pusat Statistik Provinsi Bali 2019). This is evidence of the enthusias mexperienced by foreign tourists while enjoying the natural beauty and culture of the Balinese people.

This annual increase has made the Denpasar City government to explore and increase the role of the village government in managing coastal areas. The approach has also been strengthenedby the recognition of the coastal area of Denpasar City as a tourism area through the Governor of Bali Regulation No. 23 of 2005 (Pemerintah Provinsi Bali 2005). Furthermore, the existence of village funds from the central and district/city governments provides a great opportunity for the villages to develop their own regions towards ensuring an increment in their original income (PAD).

The Biaung Beach, which includes the Ayung river estuary, is bordered by Sanur beach extending to the north and the Ketewel beach. It has been discovered to be one of the beaches in Kesiman Kertalangu Village with the potential to be developed as a new coastal tourism area. 
The natural scenery of the Ayung river estuary attracts people's attention for recreation, gathering, or just resting. This is in line with the findings of Khakhim et al. (2018) that the beauty of nature visually provides meaning to a landscape and also determines the reaction of observers (Khakhim et al. 2008). This means the beauty has the ability to increase the enthusiasm of the community to visit the place. The area has received government attention as observed from the repair of backrest and provision of jogging track facilities and has continuously been used by the community for competition and cultural arts performances.

The numerous potentials and natural beauty of the area make it suitable to be developed as a coastal tourism area. According to Zahra et al. (2014), evaluating visual quality is important to the maintenance and improvement of landscape beauty (Zahra, Sitawati, and Suryanto 2014). Moreover, landscape arrangement through visual method has been reported to have the ability to increase visitors to an area and this further provides economic benefits (Budiyono and Soelistyari 2016). Therefore, this research was conducted to evaluate the beauty of the Agung River Estuary for consideration in further planning of the area.

\section{Method}

The aesthetic quality was assessed using a quantitative approach while Scenic Beauty Estimation (SBE) was used for analysis (Daniel and Boster 1976b). This is an interactive concept which assesses the perceived conditions of a landscape and several other criteria of the as sessor (Budiyono 2015). This method was found by Fitriyani and Mardiatno (2016) to be very effective and reliable in assessing the beauty of a landscape. Moreover, the data were collected using two techniques including observation and in-depth interviews as well as questionnaires.

The research was conducted at the Tangtu River Estuary, Kesiman Kertalangu Village, East Denpasar sub-District, Bali Province with the location presented in figure 1 .

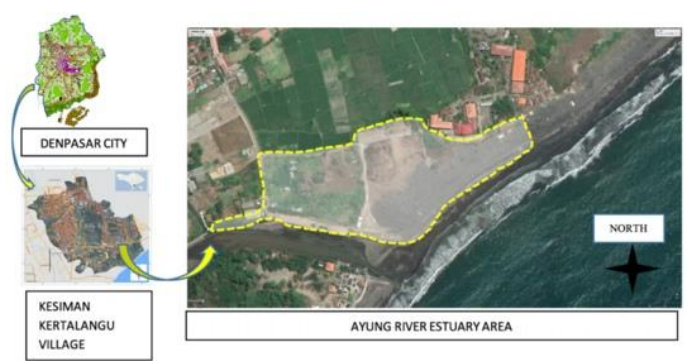

Figure 1. Research location

The key informants interviewed include the Heads of Hamlets, youths, the environment, and communities that frequently visit the research location. Meanwhile, the data source from the landscape architecture students in the 6th semester was used to evaluate the site aesthetics due to their knowledge of landscape sciences which is required for the assessment of visual landscape in accordance with the findings of Syahat, Putra, and Patih (2017). A total of 30 students was, therefore, used as informants.

Purposive sampling technique was used to determine the other informants using certain considerations (Sugiyono 2019). This method was used due to the fact that not all the people in the community understand the potential of the Ayung River Estuary area. Moreover, the questionnaire was designed in the form of an as sessment table based on 28 photo slides from 10 activity areas on the site which represent the visual conditions. The photographs were captured jointly at each location under a clear weather condition from $10.00 \mathrm{am}-02.00 \mathrm{pm}$ Bali's time and from the perspective of a human in a standing position (Hamdani 2017). Those with the highest quality were, therefore, selected to represent the character of the landscape.

Slideshows were made within one minute for each landscape sequentially from the south to the north entrance in line with the photo viewing time disclosed by Wardiningsih, Syafruddin, Syahat, et al. (2017) to ensure there is enough time to assess them. Moreover, a score of 1 was made the minimum to show the landscape is not beautiful while the maximum is 10 and this indicates the most beautiful landscapes (Daniel and Boster 1976a). The as sessment was conducted repeatedly three times to ensure certainty in determining beauty value.

The second analysis was conducted using the following formula:

$\mathrm{Zij}=(\mathrm{Rij}-\mathrm{Rj}) / \mathrm{sj}$.

(Daniel and Boster 1976a) 
Where:

$\mathrm{Zij}=$ standard $\mathrm{z}$-value for the $\mathrm{I}-1$ and $\mathrm{j}$-observer;

$\mathrm{Rij}=$ all the mean for the observer ratings to $-\mathrm{j}$;

$\mathrm{Rj}=$ the $\mathrm{i}^{\text {th }}$ value of the $\mathrm{j}^{\text {th }}$ observer;

$\mathrm{Sj}=$ the standard deviation of all $\mathrm{j}^{\text {th }}$ observed values.

The $\mathrm{z}$ value was calculated in the tabulation for each landscape as well as the frequency (f), cumulative frequency (cf), and cumulative probability (cp). A comparison was drawn between the SBE calculation values with average $\mathrm{Z}$ value close to 0 using the following formula:

$\mathrm{SBEx}=[\mathrm{Zx}=\mathrm{Zs}] \mathrm{x} 100$ (2)

Where:

(Daniel and Boster 1976a)

SBEx $=$ the estimated value of the $x^{\text {th }}$ view beauty;

$\mathrm{Zx} \quad=\mathrm{Z}$-average value of the $\mathrm{x}$-landscape landscape;

$\mathrm{Zs} \quad=$ average $\mathrm{z}$ landscape value used as standard.

\section{Result and discussion}

The physicalcondition of the Ayung river estuary area

The Ayung river estuary is in the administrative area of the Banjar Tangtu, Kesiman Kertalangu Village, and observed to be at an altitude of $0-6 \mathrm{~m}$ above sea level, beach length of $359.44 \mathrm{~m}$, and an area of 5.19 ha based on the field observations. The area also has a river width of $45-50$ meters with land slopes ranging from $0-2 \%$. Moreover, the information from Made Sudarsana as the Banjar Tangtu Hamlet Head showed the existence of two certificates for land ownership status and these include the north owned by Banjar Tangtu and the south by the Bali Provincial Government. The area was also observed to be bordered in the:

a. North bordered by Br. Tangtu rice fields;

b. East by Br. Biaung;

c. South by the Indian Ocean;

d. West by the Padanggalak area as shown in figure 2 .

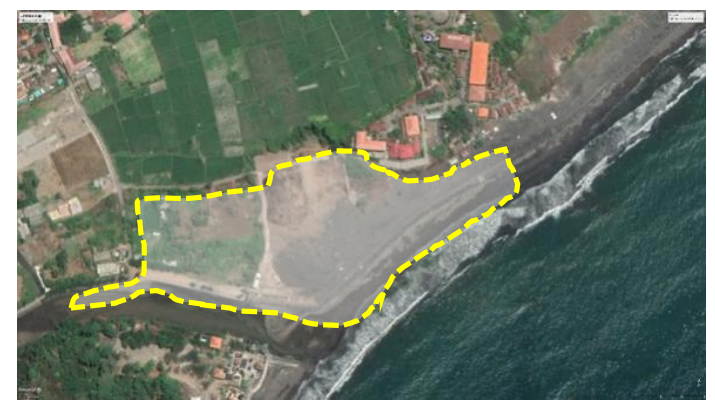

Figure 2. The Ayung river estuary area

The Ayung river estuary area is physically an empty land with several sections stretching over some areas covered with black sand. The local community uses this area for banana plantation, graveyard, and recreation. The local government has, however, made efforts to develop the coastal area through the provision of jogging track facilities along $350 \mathrm{~m}$ on the beach, 4 gazebos, and 4 stalls. There are also residences, laundry businesses, temples, and community-owned cattle sheds in the area.

The pattern of the Ayung river estuary areas is shown more clearly in figure 3 .

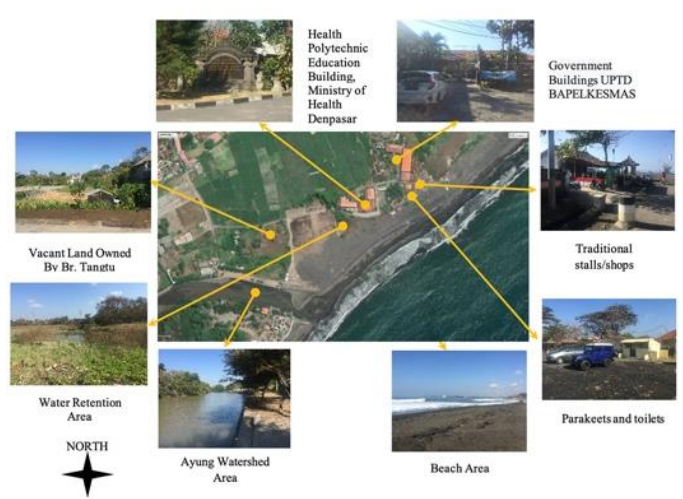

Figure 3. The phy sical condition of the existing Ayung river estuary area

The Ayung river estuary area is divided based on several uses of lands such as religious areas, community ownership land, coastal areas, and tourism support facilities.

The physical conditions of the area are described as follow:

a. The Ayung River estuary area has several temple areas including those located in the West which are local temples occupied by the Tangtu Banjar community with an approximately $2000 \mathrm{~m}^{2}$ area. There is also a Grave/Setra with an approximately $1015 \mathrm{~m}^{2}$ area in the north managed by the Banjar 
Tangtu community. They were both observed to have physical conditions which are preserved very well.

b. The areas in contact with dominant seawater have physical rocky conditions with most found along the coastline to be shipment debris either from the Ayung river mouth or the sea. A parapet was also used as a barrier to coastal abrasion at several points. Moreover, the tread beach material was observed to be black-gray sand sediment which is a type of Lithogeneous sediment formed from terrigenous and volcanic processes on the land. They were carried by rivers to the sea and distributed through currents towards the mainland (Radnyamita 2001).

c. The area belongs to Banjar Tangtu and some other lands were also observed to be owned by the community. Meanwhile, the land is located to support the community's economy and this is evident from the existence of the laundry business which was reported to have started with the improvement in the road infrastructure through paving and development of villas around the area.

d. The development of the area is as sociated with the visitation by several people and this has further led to the development of tourism support facilities such as stalls to sell varieties of food and beverages, rest areas or gazebos, toilets, vehicle parking space, ticket posts, park chairs, paths, and trash cans.

e. The estuary area is fed by the Ayung River which passes through Badung Regency and Denpasar City and is found to be one of the major rivers in Bali. The local government consistently maintains the river flow because of its use as a primary irrigation channel directly emptied into the sea. Moreover, there are villa buildings and temporary garbage dumps serving Kesiman Kertelangu Village along the watershed in this area. The Ayung river estuary was recorded to be at approximately 1-3 $\mathrm{m}$ depth from the surface. Its watershed was found to be the place most visited by the community for fishing activities and recreation. Meanwhile, the river has been reported by Giostanov (2018) to be $62.5 \mathrm{~km}$ longer than the Badung River.

The Ayung river estuary area site was found to be close to educational facilities, agricultural Kawasasan, sacred areas, office areas, and residential areas and also approximately $200 \mathrm{~m}$ from the Diyatmika International School, directly from the Ministry of Health's Health Polytechnic education building, and the Health polytechnic nutrition academy study program. The educational activities are not only conducted inside the buildings with the students and staff allowed to perform certain activities outside the school such as taking a leisurely walk, cleaning the environment, and engaging in sports.

The condition of vegetation and animals in the area

Ayung river estuary is located in a coastal area and the types of vegetation existing in the area have the ability to live and adapt well to sea breezes and soil salinity such as banana (Musa acumenata), cassava (Manihot esculenta), and papaya (Carica papaya L.). Some of the shade trees discovered include Waru (Hibiscus tiliaceus), Angsana (Pterocapus indicus), Ketapang (Terminalia catappa), and sea pine (Casuaria equesetifolia). Meanwhile, the plants used to support the site aesthetics are Jepun (Plumeria rubra), Parasok (Dracaena draco), Sea Pandanus (Pandanus odorifer), Princess Palm (Roystonea regia), Squirrel-tailed Palm (Wodyetia bifurcata), Paper Flower (Bougenvile $s p$ ), Banana ornamental (Heliconia golden 'torch'), and Banana Karibea (Heliconia caribea).

The results of the interviews conducted with local fishermen showed some catches in the Biaung coastal waters include surface and some migratory fishes for consumption such as mackerel (Scomberomorus sp), mackerel (Euthynusaffinis), tuna (Thunus sp), GT (Caranx ignobilis) and lemuru (Sardinela sp). Some locations were observed to involved the use of fishermen's reefs as traps to catch lobsters (Nephropidae sp). Moreover, Ayung river estuary was reported to have brackish water types of fish such as lemujung or bojor (Sand whiting) and baung (Mystus nemurus) while the unspoiled condition in the Ayung river estuary area makes it a suitable habitat for lizards (Varanus salvator) and snakes (Serpentes sp).

\section{Local socio-cultural conditions}

The social and cultural conditions of the local community, especially Banjar Tangtu, are very strong with the sense of community and environment observed not to have been reduced by urbanization. This is evident in regular activities such as mutual cooperation to invite newcomers to participate in the maintenance of the cleanliness and safety of the environment. 
These are observed in Banjar and environmental roads covering the Ayung River Estuary Area.

The coastal area is often used by the local community as a place for melukat (cleaning themselves from negative elements). This involves praying around the beach and cleansing of bodies by bathing with seawater. The beach sand was also observed to be used by the people to soak or bury their bodies in the morning. This is believed to have a relaxing effect on muscles and bones due to the ability of the black beach sand to provide a warm feeling to the body.

Manusa Yadnya for religious ceremonies such as Ngayud, Ngotonin, and Melis is often used by the Kesiman Kertalangu Village people and this leads to the crowding of the beach with Hindus on religious days to offer prayers.

\section{Local art condition}

The Ayung river estuary area is often used by Seka Truna-Truni or the community to conduct artistic performance activities such as music, dance, and bazaar events to generate income for local people selling in the area. Some other activities include competitions such as kite, pindekan, sunari, and lelakut.

The Ayung river estuary area beauty value

The Scenic Beauty Estimation (SBE) assessment used in this study categorized the classes of value into high, medium, and low. The elements of the landscape were analyzed using this method with the area distribution shown in figure 4.

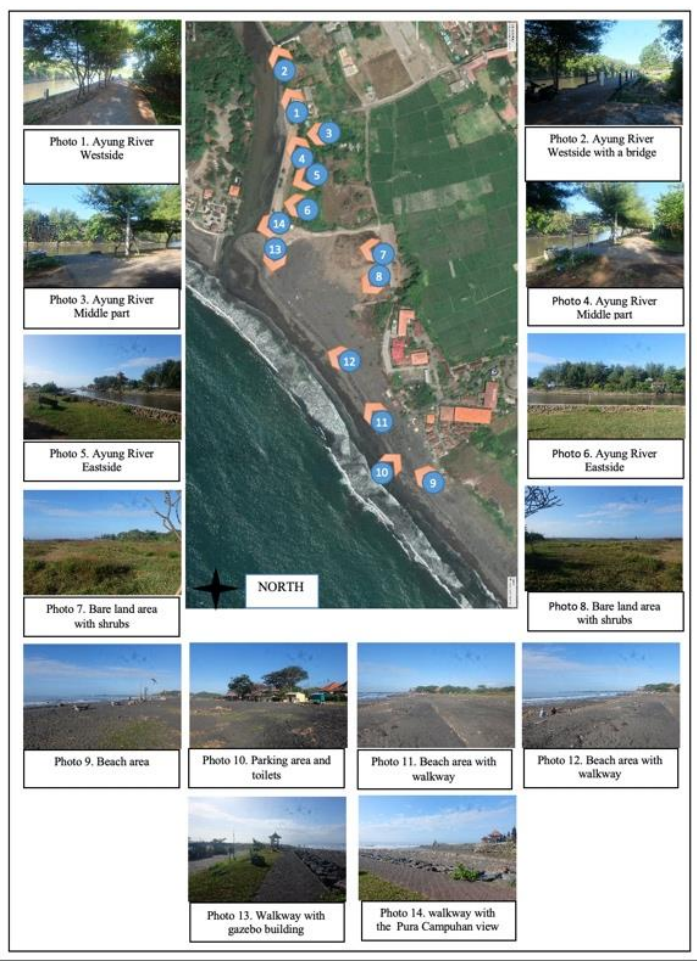

Figure 4. Scenic Beauty Estimation (SBE) distribution values in the Agung river estuary area

The categories were determined by dividing the highest value into the specified numbers and the data showed most of the visual landscapes in the area are classified as moderate-low with only a few having a beautiful visuallandscape value as shown in table 1.

Table 1. The landscape beauty value

\begin{tabular}{lll}
\hline \multicolumn{3}{l}{ Value category landscape be auty } \\
\hline Class & De viation & Photo \\
\hline Low & $0-26.27$ & $3,4,9,10,11$, and 12 \\
Middle & $26.28-52.55$ & $6,7,8,13$, and 14 \\
High & $52.56-78.81$ & 1,2, and 5 \\
\hline
\end{tabular}

The Scenic Beauty Estimation (SBE) analys is showed the lowest landscape beauty value was in photo 10 which is the northern vehicle parking area and selected due to the less orderliness of the facilities, lack of uniformity in the buildings and materials used, site cleanliness, and wild vegetations in the form of grass-dominated by black sand. Meanwhile, photo 13 was clas sified as moderate. This is the Ayung river estuary area with views of the walkway, grass, retaining walls, stalls, gazebos, and the ocean. The classification was based on the numbers of objects seen, consistency, and material firmness and neatness. Moreover, the highest beauty value was found at 
the landscape view with tight tree stands which create a shady impression, calm river flow, and site cleanliness. The results of the visual values based on the categories in each photo are presented in figure 5 .

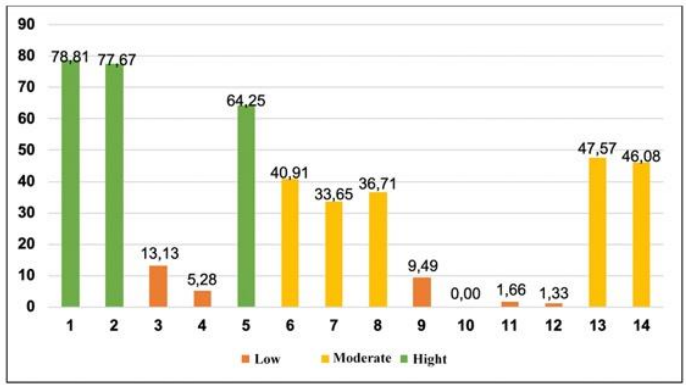

Figure 5. The Scenic Beauty Estimation (SBE) distribution categories for landscape photo beauty value

The analysis showed 6 pieces of photos in the low beauty category and they include Ayung river middle area ( 3 and 4$)$, beach area near parking lots and toilets (9 and 10), and beach area with a walkway (11 and 12). Meanwhile, 5 photos are classified under moderate value and these are Ayung river area eastern side (6), empty land areas with shrubs (7 and 8), and walkway area with gazebo buildings and Campuhan Temple. Three photos were, however, found to have a high beauty value and these include westside (1 and 2) and eastern side with views of the sea and the Campuhan Temple (5). Furthermore, the factors influencing the micro-determination of the area presented in the following table 2.

Table 2. The determinants of beauty in the Ayung river estuary area

\begin{tabular}{|c|c|c|c|c|}
\hline No & $\begin{array}{l}\text { Photo } \\
\text { location }\end{array}$ & $\begin{array}{l}\text { The } \\
\text { n }^{\text {th }} \\
\text { photos }\end{array}$ & $\begin{array}{l}\text { Beauty } \\
\text { category }\end{array}$ & $\begin{array}{l}\text { Landscape } \\
\text { beauty } \\
\text { determinants } \\
\text { in Ayung river } \\
\text { estuary area }\end{array}$ \\
\hline \multirow[t]{2}{*}{1} & $\begin{array}{l}\text { Ayung } \\
\text { River } \\
\text { West side }\end{array}$ & 2 & \multirow[t]{2}{*}{ High } & $\begin{array}{l}\text { - Regular and } \\
\text { consistent } \\
\text { vegetation } \\
\text { stands }\end{array}$ \\
\hline & $\begin{array}{l}\text { Ayung } \\
\text { River } \\
\text { Cushion } \\
\text { Westside }\end{array}$ & 5 & & $\begin{array}{l}\text { - Shady } \\
\text { - Calm water } \\
\text { elements } \\
\text { (sea and } \\
\text { river) } \\
\text { - Clean } \\
\text { - The aesthetic } \\
\text { form of the } \\
\text { bridge, Pura } \\
\text { Campuhan } \\
\text { Windhu } \\
\end{array}$ \\
\hline
\end{tabular}

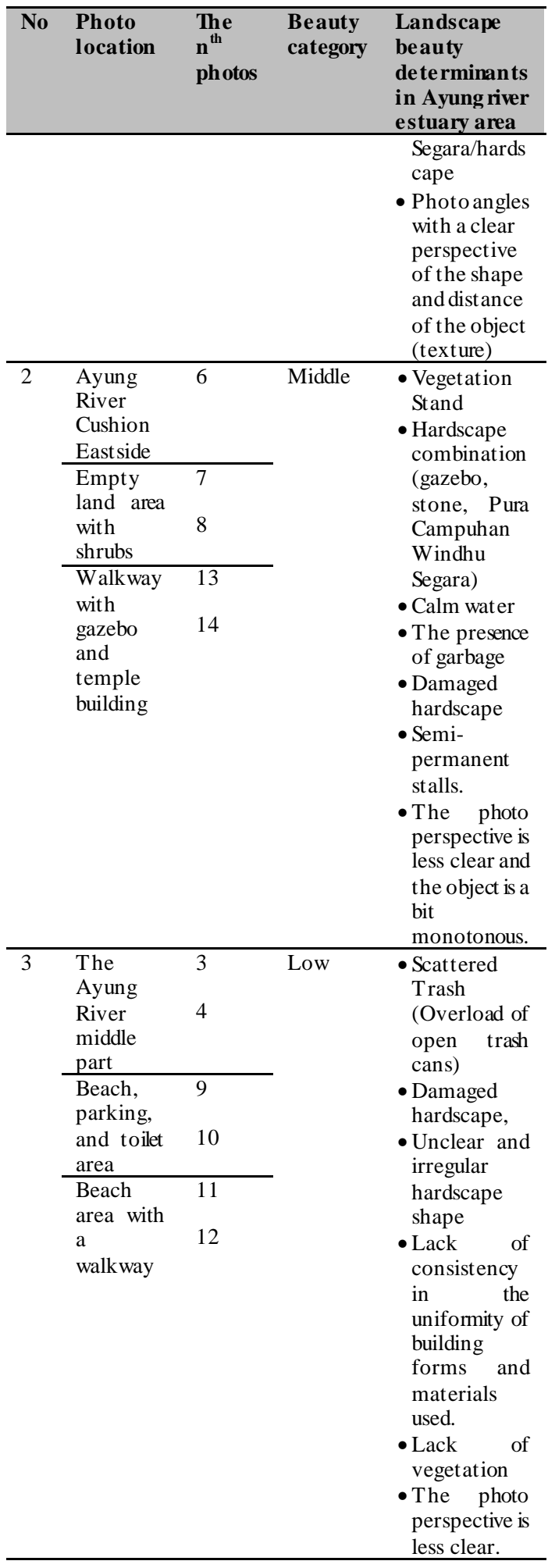

The table shows the factors influencing the micro-determination beauty value in the landscape to be vegetation, water elements, 
cleanliness, aesthetic forms of hardscape or landscape elements, and shade. These results are also in line with the studies conducted by Dewi and Sarilestari (2018) which found vegetation to be one of the important physical elements in environmental design and management. This means the size, shape, color, and texture of vegetation supports the beauty of an area. The same was expressed by Putra (2018) that there is a need to arrange plants with complete strata such as ground cover, shrubs, and trees in order to increase a site's visual value. Putra et al. (2018) further showed the planning of landscape requires the arrangement of vegetation to create a beautiful site (R. T. Putra et al. 2018). The diversity of soft materials or plant elements also affect the landscape visual value (Budiyono, Nurlaelih, and Djoko 2012). Furthermore, Syahadat and Putra (2020) reported the need for the selection and arrangement of vegetation with less dense shrubs composition in order to add to site aes thetics.

The Ayung river estuary is a coastal area dominated by empty land and black sand beaches. It has some similarities from the macro-level used in determining the microsite beauty and these include vegetation density and color which affect the visual assessment as observed in the Ayung River estuary southern area or the Campuhan Windhu Segara Temple area. This finding is in line with the study by Titi and Gunawan (2011) where plant colors were reported to be providing attractiveness through the avoid ance of monotony in the landscape. Lesser vegetation was reported to have reduced the site aesthetic value and this means it is one of the attributes used in improving landscape quality (Poerwoningsih, Santoso, and Winansih 2016). Meanwhile, the collection of building masses was discovered not to have a significant influence on the beauty value of the landscape while architectural aesthetics was found to have a substantial effect. This is in line with the studies of Adriani, Hadi, and Nurisjah (2016) that low landscapes visual value is due to unorganized buildings as well as the visual completeness from unity, proportion, rhythm, scale, and color (Alindo, Chalim, and Mangungsong 2018) as presented in figure 6.

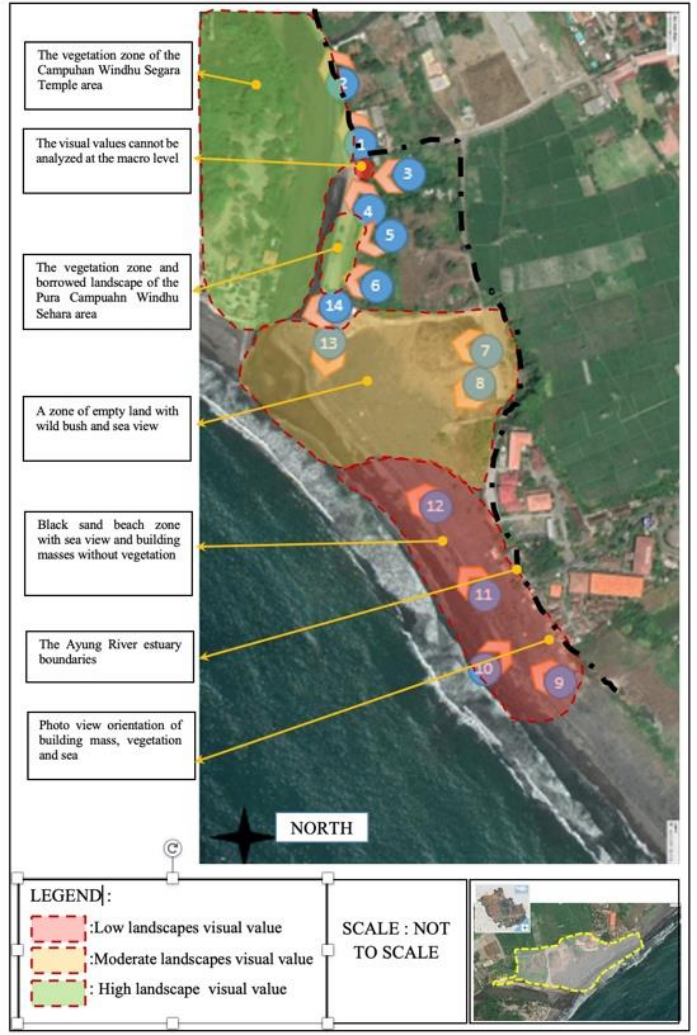

Figure 6. Visual value distribution map for the Ayung river estuary landscape

\section{Conclusion}

The Ayung river estuary area is included in the moderate to low beauty category based on a scenic beauty estimation analys is conducted on 14 landscape photos. The sections found to be in the high category were on the river banks in the western part while those in the low category are on the coastal area to the north. Moreover, the scenic beauty estimation determination value was discovered to be influenced by micro factors such as the presence of vegetation, water elements, cleanliness, and hardscape or landscape elements in aesthetic forms. The area has some similarities from the macro-level used in determining the microsite beauty and these include vegetation density and color which affect the visual assessment as observed in the Ayung river estuary southern area or the Campuhan Windhu Segara Temple area. Furthermore, lesser vegetation was reported to have reduced the site aesthetic value and this means it is one of the attributes used in improving landscape quality 


\section{References}

Adriani, Hanni, Setia Hadi, and Siti Nurisjah. 2016. 'Perencanaan Lanskap Kawasan Wisata Berkelanjutan Di Kecamatan Cisarua, Kabupaten Bogor'. Jurnal Lanskap Indonesia 8 53-69. https://doi.org/10.29244/jli.2016.8.2.53-69.

Alindo, Risa Monika, Abdul Chalim, and Nur Intan Mangungsong. 2018. 'Pengaruh Aspek Estetika Visual Untuk Pengembangan Lanskap Bogor Green Forest Resort, Bogor, Jawa Barat'. In Seminar Nasional Kota Berkelanjutan, 1:218. Jakarta: Universitas Trisakti. https://doi.org/10.25105/psnkb.v1i1.2901.

Badan Pusat Statistik Provinsi Bali. 2019. 'Perkembangan Pariwisata Bali'. Bali. https://bali.bps.go.id/pres srelease/2019/03/01 /717182/perkembangan-pariwis ata-balijanuari-2019.html.

Budihardjo, Rachmat. 2019. 'Pengaruh Pariwis ata Pada AdaptasiFungsi, Bentuk Dan Ruang Arsitektur Puri, Studi Kasus: Puri Saren Agung Ubud'. ARTEKS : Jurnal Teknik Arsitektur 4 (1): 63-72. https://doi.org/10.30822/arteks.v4i1.80.

Budiyono, Debora. 2015. 'Evaluasi Estetika Lingkungan Berdasarkan Persepsi Di Welcome Area Kampus Institut Pertanian Bogor'. Jurnal Penelitian Ilmu-Ilmu Kelaman Buana Sains $15 \quad$ (1): 19-28. https://jurnal.unitri.ac.id/index.php/buanasain s/article/view/346.

Budiyono, Debora, Euis Elih Nurlaelih, and Riyanto Djoko. 2012. 'Lanskap Kota Malang Sebagai Obyek Wisata Sejarah Kolonial'. Jurnal Lanskap Indonesia 4 (1): 43-50. https://doi.org/10.29244/jli.2012.4.1.\%p.

Budiyono, Debora, and Hesti Triana Soelistyari. 2016. 'Evaluasi Kualitas Visual Lanskap Wisata Pantai Balekambang Di Desa Srigonco, Kabupaten Malang'. Jurnal Lanskap Indonesia 8 (2): 81-90. https://doi.org/10.29244/jli.2016.8.2.81-90.

Daniel, Terry C., and Ron S. Boster. 1976a. 'Measuring Landscape Esthetics: The Scenic Beauty Estimation Method'. USDA Forest Service Research Paper. https://doi.org/10.1017/CBO9781 107415324. 004.

1976b. Measuring Landscape Esthetics: The Scenic Beauty Estimation Method. USDA
Forest Service Reseach Paper. https://www.fs.fed.us/rm/pubs_rm/rm_rp167. pdf.

Dewi, Euis Puspita, and Wulan Sarilestari. 2018. 'Penilaian Kualitas Estetika Lanskap Kota Bogor Dengan Menggunakan Scienic Beauty Estimation (SBE)'. IKRA-ITH Teknologi Jurnal Sains Dan Teknologi 2 (2): 1-8. https://journals .upiyai.ac.id/index.php/ikraithteknologi/article/view/462/344.

Fitriyani, Kiki Rizki, and Djati Mardiatno. 2016. 'Analisis Kesesuaian Lahan Dan Nilai Keindahan Lanskap Untuk Pariwisata Pesisir Dan Pantai Di Kecamatan Sanden'. Jurnal Bumi Indonesia 5 (4): 1-11. http://lib.geo.ugm.ac.id/ojs/index.php/jbi/arti cle/view/847.

Giostanov, Alfonso. 2018. 'Kondisi Sungai Ayung'. Gotravelaindonesia. 2018. https://www.gotravelaindonesia.com/kondisisungai-ayung/.

Hamdani, Nurjannah. 2017. 'Evaluasi Estetika Air Pancuran Pada Taman Suropati; Semantic Differential Dan Scenic Beauty Estimation'. Faktor Exacta 10 (4): 406-13. https://journal.lppmunindra.ac.id/index.php/F aktor_Exacta/article/view/2246/1715.

Khakhim, Nurul, Dedi Soedharma, Ani Mardiastuti, Vincentius P. Siregar, and Mennofatria Boer. 2008. 'Analisis Preferensi Visual Lanskap Pesisir Daerah Istimewa Yogyakarta Untuk Pengembangan Pariwisata Pesisir Menuju Pada Pengelolaan Wilayah Pesisir Berkelanjutan'. Forum Geografi 22 (1): 44. https://doi.org/10.23917/forgeo.v22i1.4925.

Pemerintah Provinsi Bali. 2005. Peraturan Gubernur Bali Nomor 23 Tahun 2005 Tentang Zonasi Pemanfaatan Wilayah Pesisir Dan Laut Bali Tenggara. Indonesia: PERGUB Bali. https://jdih.baliprov.go.id/produkhukum/peraturan/abstrak/5823.

Poerwoningsih, Dina, Imam Santoso, and Erna Winansih. 2016. 'Sense of Place Masyarakat Terhadap Karakter Lanskap Kawasan Bumiaji, Kota Batu'. In Temu Ilmiah IPLBI 2016, 101-6. Malang: Fakultas Teknik Sipil dan Perencanaan Institut Teknologi Nasional. https://temuilmiah.iplbi.or.id/wpcontent/uploads/2016/12/IPLBI2016-A-101 106-Sense-of-Place-Mas yarakat-Terhadap- 
Karakter-Lanskap-Kawas an-Bumiaji-KotaBatu.pdf.

Putra, Priambudi Trie. 2018. 'Persepsi, Preferensi Dan Perilaku Masyarakat Terhadap Konsep Ecodesign Lanskap Permukiman'. Tesa Arsitektur $\quad 16 \quad$ (1): 20-28. https://doi.org/https://doi.org/10.24167/tesa.v 16i1.1113.

Putra, Ridwansyah Trisnanda, Daisy Radnawati, Ray March Syahat, Priambudi Trie Putra, and Dimas Muhammad Thoifur. 2018. 'Evaluasi Taman Jangkrik Sebagai RTRA Di Ciganjur, Jakarta Selatan'. In Seminar Nasional Sains Dan Teknologi, 1-8. Jakarta: Fakultas Teknik, Universitas Muhammadiyah Jakarta. https://jurnal.umj.ac.id/index.php/semnastek/ article/view/3465/2613.

Radnyamita, I. G. A. 2001. 'Kajian Pengelolaan Sumberdaya Pesisir Di Kota Denpasar Ditinjau Dari Aspek Perikanan Dan Pariwisata Dihubungkan Dengan Rencana Umum Tata Ruang Wilayah Kota Denpasar'. Denpasar.

Sugiyono. 2019. Metode Penelitian Kuatintatif, Kualitatif Dan R\&D. Alfabeta. 2nd ed. Bandung: Alfabeta. https://doi.org/2008.

Syahadat, Ray March, and Priambudi Trie Putra. 2020. 'Manfaat Visual Keberadaan Hutan Kota Padang Golf Halim'. Jurnal Arsitektur $\begin{array}{llll}\text { Lansekap } & 6 & \text { (1): } & \end{array}$ https ://doi.org/10.24843/JAL.2020.v06.i01.p 12.

Syahat, Ray March, Priambudi Trie Putra, and Tandri Patih. 2017. 'Meningkatkan Keindahan Arsitektural Jembatan Surya Lembayung Kebun Raya Bogor Dengan Tanaman Lanskap'. Jurnal Arsitektur Lansekap $\quad 3 \quad$ (1): 23-31. https ://doi.org/10.24843/JAL.2017.v03.i01.p 03.

Titi, Wasissa, and AndiGunawan. 2011. 'Pers epsi Dan Preferensi Warna Dalam Lanskap'. Jurnal Lanskap Indonesia 3 (2): 73-79. https ://journal.ipb.ac.id/index.php/jli/article/v iew/5760.

Wardiningsih, Sitti, Asep Syafruddin, Ray March Syahat, and Priambudi Trie Putra. 2017. 'Kajian Pencirian Visual Lokasi Wisata Kota Batu Di Malang'. Jurnal SCALE 5 (1): 66-75. http://repository.uki.ac.id/183/1/KAJIAN PENCIRIAN VISUAL LOKASI WISATA KOTA BATU DI MALANG.pdf.

Zahra, Amelia Firdaus, Sitawati, and Agus Suryanto. 2014. 'Evaluasi Keindahan Dan Kenyamanan Ruang Terbuka Hijau (Rth) Alun-Alun Kota Batu'. Produksi Tanaman 2 (7): 524-32. http://protan.studentjournal.ub.ac.id/index.ph p/protan/article/view/140/136. 
ARTEKS : Jurnal Teknik Arsitektur, Volume 6 Issue 1, April 2021

pISSN2541-0598; eISSN2541-1217 